\title{
PEDAGOGICAL FACTORS OF DEVELOPING A SCIENTIFIC WORLD-VIEW IN SCHOOL STUDENTS ON THE BASIS OF THE HERITAGE OF OUR GREAT ANCESTORS THROUGH TEACHING HISTORY
}

\author{
Jaxongir Yunusaliev
}

Independent Researcher Of Kokand State Pedagogical Institute, Uzbekistan

\section{ABSTRACT}

The article analyzes the pedagogical factors of developing students' scientific outlook on the basis of historical sources based on the heritage of our great ancestors through the teaching of history.

KEYWORDS:- Scientific worldview, excursion, historical memory, pedagogy, historical source, historical location, scientific novelty.

\section{INTRODUCTION}

It is not enough to master the scientific basis of teaching history to know the purpose of teaching history in school, the educational tasks and content of education. The teaching of history, as well as the study of historical materials by students, will continue in extracurricular activities. The system of history lessons, in particular, the choice of this or that type of history lessons is based on the ideological content of the history program material, its educational and pedagogical tasks and the general preparation of students. At the same time, the need to use different types of history lessons stems from the richness and diversity of the content of the history program, as well as the educational laws. The pedagogical analysis of the development of the scientific worldview in students on the basis of the heritage of our great ancestors through the teaching of history can be theoretically substantiated. The use of different types of history lessons system, tested in the experience of advanced students, contributes to the successful implementation of the educational tasks of the school history course.

In the history of pedagogy, there were two main directions in the division of lessons into types:

Proponents of the first direction divide lessons into types based on the laws of the teaching process.

One of the representatives of the second direction, IN Kazantsev, bases his teaching methods on the classification of types of lessons $[67,126]$. However, even in this context, advanced teachers have successfully used advanced methods and techniques in the field of 
CURRENT RESEARCH JOURNAL OF PEDAGOGICS 2(6): 57-61, June 2021

DOI: https://doi.org/10.37547/pedagogics-crjp-02-06-12

ISSN 2767-3278

(C)2021 Master Journals

\section{Crossref do) 81 Google}

Accepted 11 th June, 2021 \& Published $16^{\text {th }}$ June, 2021

history teaching, a variety of types of lessons.

The new content of history education in the school and the tasks of further development of students' scientific outlook open up great opportunities for improving the forms and methods of teaching history.

The laws of the educational process, their main stages, the basis for further development of school students' scientific outlook (preparation of students for the understanding of historical events, acquaintance with the material, its analysis, generalization, consolidation, formation of skills and abilities, teaching students to apply knowledge in practice) is obtained. At each stage of the scientific study of history, the method of teaching is selected according to the content of the material.

The classification of history lessons, the further development of the scientific worldview, the use of its diversity stems not from the personal wishes of the teacher, but from the purpose of the school history course, the need for successful implementation of educational tasks and the basic laws of history education.

\section{Materials AND METHODS}

R.H.Djuraev, B.H.Rakhimov, R.G. Safarova, A.A.Ahmedov, H.A.Turakulov, on the basis of scientific research activities, creative activity of students in our country on the formation of research skills in students in the world education system. N.O.Usmanov, N.A.Atakulova, O.X.Turakulov, A.R.Khodjaboev, B.Yu.Khodiev, A.Sh.Bekmurodov, M.R.Boltabaev, L.V.Golilish, I.Pedagogical scientists such as B.Askarov, psychologists E.Gaziev, M.G.Davletshin, V.Karimova, Z.Nishonova, R.Sunnatova, Sh.T.Khalilova are recognized for their psychological problems of directing young people to research activities.

\section{RESULTS AND DISCUSSION}

Not all of the knowledge and skills that students need to learn in a history program can be incorporated into a lesson. In addition, in addition to the classroom, it is necessary to organize excursions to existing historical sites, so that students can develop a scientific outlook in the context of expanding the volume of historical knowledge, scientific and political news. This form of education provides a convenient environment for the use of additional materials on historical topics, including historical maps. At the same time, it should be noted that the use of historical maps serves as an aid to the study and understanding of historical events in the lessons of Uzbek and world history. In this process, of course, certain educational laws, didactic requirements must be followed.

When the teacher uses historical addresses and maps for use in history lessons:

- A vivid description of historical events provided for in the school program;

- $\quad$ To show the living conditions of historical figures, statesmen and public figures and the people;

- It will be necessary to choose works that describe the places where important historical events took place and the exact conditions of those places.

As the political scientist N.Juraev noted in his "Concept of restoration and creation of historical memory" "... through the understanding of history, the ability to understand life, to understand the humanity of man is formed."

In this process, Babur describes the different regions, cities, districts and villages of Movarounnahr and thinks about their geographical area, nature, climate, flora and fauna. 
CURRENT RESEARCH JOURNAL OF PEDAGOGICS 2(6): 57-61, June 2021

DOI: https://doi.org/10.37547/pedagogics-crjp-02-06-12

ISSN 2767-3278

(C)2021 Master Journals

\section{Crossref do) 81 Google}

Accepted 11 th June, 2021 \& Published $16^{\text {th }}$ June, 2021

In short, Boburnoma describes all aspects of his work as truthful. After all, the future of our independent and free-thinking youth will serve for the glory and future of our great country.

Experience and analysis show that in the teaching of history of Uzbekistan and the world, historical maps and historical sources are rarely used in school practice. In fact, there are many sources of literature and images that can be used in history lessons. Including,

- $\quad$ Historical miniatures created on the basis of documents on real historical events, as well as miniature works of art created during the historical process, miniatures for "Zafarnoma" and "Boburnoma".

- Scientifically based, reconstructed paintings of architecture and other monuments, miniature works of art on historical themes created by artists. For example, the well-known architect scientist D. Fozilov's reconstructed miniature projects about Tpaqrqala, academician G. Pugachenkova's fundamental scientific works on ancient historical architectural monuments, as well as A. Aliqulov, Z. Faxriddinov, M. The use of Nabiev's works as a didactic opportunity is one of the important tools to increase the effectiveness of history lessons.

"History in teaching - writes N.V.Andrevskaya, xususiyati The nature and significance of the lesson, which uses visual aids on the subject of history, is that in this case the teacher will be able to draw appropriate conclusions through the perception of the past. When verbal images are used as a basis for introducing students to the past, the teacher leads students to understand the past through miniature images, "experiencing" and "feeling" [32]. Demonstrative method of teaching history, visualization of the teacher's statement, his ability to rely on readymade images, the use of visual aids in the presentation of educational material and the activation of students' cognitive activity through visual aids and their own or their images learning is of great educational and pedagogical importance.

While the use of historical sources, documents, and historical map artwork illustrates a teacher's speech, visual aids provide students with a vivid and clear picture of the past, adding visual and other sensory activities to students 'auditory activities. At the same time, students' perceptions of historical events and happenings are realized, their knowledge is deepened and strengthened by identification through concrete images, which is an important didactic tool to increase the effectiveness of teaching history.

The use of historical works in history is of great educational and pedagogical significance. First of all, historical works serve as an important source of knowledge. Even when the teacher's lecture is complete, the students 'perceptions of the events are not complete. For example, in the work "Zafarnoma" in miniatures of the XV century fully describes the life and work of Amir Temur. The reader cannot imagine the military marches, ceremonies, etc. of Amir Temur without seeing them. It is also impossible to imagine clearly and deeply the historical landscape of the period under study without the use of miniature works of art on a historical theme.

Historical sources help students to form historical concepts, their theoretical conclusions and generalized conclusions to better understand the interrelationships of the objective laws of social development. It also serves as an important means of educating students aesthetically.

It is worth noting that the principle of multiplicity in the depiction of reality, usually in historical maps and sources, is the aesthetic approach of Eastern artists, in which the multiplicity of characters, the abundance of 
elements (nature, architecture, clothing, weapons, animals, etc.) can complicate it a bit. On the other hand, it is multi-elementalism that ensures the completeness of historical facts and details. The life and experience of famous historical figures who lived before us are very useful in the artist's study of man. Because every historical person, especially a historical creative person, lives in harmony with the three components of history - the past, present and future. The study of the instructive aspects of the past, the lives of famous historical figures is an ideological and aesthetic process carried out directly with the requirements and needs of historical development, which is of particular importance for our country and our people. That is why the First President of the Republic of Uzbekistan I. A. Karimov noted that in the early years of independence in the history of Turkestan there were many encyclopedic scholars, famous commanders, statesmen, national heroes who fought against the invaders, and repeatedly acknowledged the importance of studying their activities and setting an example for our people. After all, passing on to us the experience gained by our ancestors in history will help us to understand today more deeply and take a firm step towards the future.

Thanks to independence, our country has ample opportunities to study and promote the ancient cultural heritage and spiritual values of our ancestors. One of such works is "Zafarnoma" and "Boburnoma". They are not only a unique historical encyclopedic monument, but also a source of significant educational and pedagogical value as a shining example of a miniature interpretation of historical events.

Historical sources and maps have a wide pedagogical potential as they affect the emotions and consciousness of students as the most important means of education.

The positive solution of the following tasks is an important factor in the good knowledge of students in history lessons:

- $\quad$ extensive use of historical sources and maps in history;

- $\quad$ Independent thinking on historical sources and maps to make students feel this image;

- Students understand the specifics of the event in the picture;

- $\quad$ Raising students' scientific outlook on the basis of the heritage of our great ancestors through the teaching of history.

- Developing students' interest in the science of history through historical historical sources and maps is a complex pedagogical process. The purpose of knowing this process is to cultivate in students loyalty to the motherland on the basis of the life activities, thoughts, aspirations, lifestyles, spiritual experiences of historical heroes who have manifested universal, moral qualities.

- In teaching students to love history through historical sources and maps, it is advisable to perform the following tasks:

- to arouse teachers' interest in historical sources and maps;

- to develop the ability to draw certain conclusions from them;

- to understand the life, activities, lifestyle, thoughts, spiritual experiences of the heroes in historical sources;

- $\quad$ to learn from positive heroes, to skillfully and effectively convey their inner experiences to students and to develop the ability to work with them in the course of their lives, to try to find solutions to difficulties and problems with them;

- $\quad$ increase students' interest in historical sources and maps, especially historical 
miniatures, self-awareness in students, the formation of devotion to historical memory;

- not to forget our national values, to preserve our historical heritage, to develop a sense of devotion to the motherland;

- $\quad$ Enhancing the qualities of our nation, such as faith, honesty, piety, honesty, love, modesty;

- to inculcate in the hearts and minds of students the undiscovered aspects of our history.

- The success of the positive solution of these tasks can be ensured by taking into account the following factors:

- $\quad$ History teachers have in-depth scientific knowledge of historical sources and maps;

- Availability of sufficient historical resources and maps in schools;

The interest and need of students in the study of works of art, knowledge of the life and work of the protagonists;

To arouse students' interest in historical works ("Zafarnoma" and "Boburnoma") and to organize activities aimed at promoting their ideas;

- $\quad$ Creating opportunities for the organization of reading activities in the family.

\section{Conclusion}

The above factors are important conditions for expanding the didactic opportunities to increase the effectiveness of the development of students' scientific outlook on the basis of the heritage of our great ancestors through the teaching of history.

Through historical sources and maps to teach students to better understand our history, to know who our ancestors are, to form loyalty to our country, to arouse interest in the science of history, to master their ideas, to learn from their favorite historical figures, their good qualities, patriotism, courage, diligence, devotion The development of socio-pedagogical method of formation of strong-willed qualities is of great pedagogical importance. The study of the history of our country uses all sources in history, from architecture to written sources. The appearance of the books and the maps in them give a clear and vivid picture of this period. It is clear from this that they are a source that bears witness to true history. If we could bring them into the education system, into the lives of the students, they would be able to really see the landscape of history more clearly. This, in turn, is an important didactic opportunity to teach history to students based on the heritage of our great ancestors.

\section{ReFERENCES}

1. Khaydarov S. and dr. The role of fine arts in increasing the effectiveness of history lessons in Uzbekistan // Science and Education. - 2020. - T. 1. - №. 6. - S. 174179.

2. Andrevskaya N.V. Bernadskiy V.N. Methods of teaching history. - Tashkent: "Educational-pedagogical" publishing house, 1950. 目 $184 \mathrm{p}$.

3. Axmedov B. Sources of history of Uzbekistan. - Tashkent: Teacher, 2001, $350 \mathrm{p}$.

4. Гаффаров Я. Ўзбекистон халқлари тарихини ўқитиш усуллари. - Тошкент: Университет, 1996. - 47 б.

5. Bakhromovich, S. I., \& Lutfillo, M. (2021). Development of ecological culture in students in the process of education of history of Uzbekistan. 